\title{
Embryonic Cell
}

National Cancer Institute

\section{Source}

National Cancer Institute. Embryonic Cell. NCI Thesaurus. Code C13054.

A cell formed in the first stages of embryonic development, after the splitting of the fertilized ovum, but before the formation of the blastula or blastocyst. 